\title{
INDIKATIEF EN PARAKLESE IN ROMEINE ।
}

\author{
M.A. Kruger \\ Hammanskraalse Teologiese Skool \\ Potchefstroomse Universiteit vir Christelike Hoër Onderwys \\ POTCHEFSTROOM
}

\begin{abstract}
INDICATIVE AND PARACLESIS IN THE LETTER TO THE ROMANS
\end{abstract}

The introductory pan of this anicle presents an explanation of what is meant by the Greek New Testament word ropók $\lambda$ nots and an indication of what is accepted by the author of this article as a valid method of studying Romans. The main indicative of Romans lies in the first parth 1:16- 4:25. Special attention should thus be given to the introductory pan before this main section. In deviations from the formal introduction to the letter Paul beforehand indicates what is fo follow later in the letter. The traditional exegesis of Romans 1:18 is not considered as correct in all aspects and reformed dogmatics built on Romans 1 should be reconsidered as far as sufficiency of revelation is concemed. The second main section, Romans 5-8 is a consolation and an exhortation to Christians to persevere in faith. The third pan, Romans 9-11, is an appeal to Jews to accept Jesus Christ as the Messiah. This part also contains an urgent waming to Christians from the Gentiles not to fall into covenant-automatism. The ropón $\lambda$ nors of Romans 12:1 - 15:13 is directed in first instance to the congregation in Rome. Though this paraclesis primarily concems the congregation in Rome, it also touches upon the relation to the world and to authority, and it culminates in Romans 15:7 with an appeal that the diverse groups in the congregation in Rome should accept each other as Christ had accepted them. In the concluding part of the letter Paul's main issues are to get the Romans involved in his planned missionary work in Spain and the appeal that they should bring forth the fruit of their faith. The aricle concludes with some suggestions for sermons from Romans.

\section{ALGEMENE INLEIDING}

\subsection{Paraklese}

In hierdie artikel word onder die term paraklese die volgende verstaan: oproep, appel, bemoediging, troos en bevel. Die meer algemene onderskeid wat dikwels in kommen-

${ }^{1}$ Hierdic artikel is 'n verwerking van 'n referaat wat gedurende Julie 1989 tydens 'n Winterskoolkursus van die Fakulteit Teologie van die PU vir CHO onder leiding van prof. J.C. Coetzee aangebied is. Die artikel veronderstel dus dat die leser ook die artikel van C.J.H. Venter wat as inleidende referaat tydens die kursus gedien het, gelees hel (In die Skriflig 24(1) 1990:1-27). 
tare gemaak word, naamlik dogmatiese en etiese dele van briewe, is minder bevredigend. Ook die onderskeiding indikatief en imperatief is nie bevredigend nie, want met die term imperatief word die klem makliker geplaas op 'n wettiese verhouding waar bevele gehoorsaam moet word. As gevolg hiervan word die vader-kindverhouding te min beklemtoon. Paraklese het 'n ruimer inhoud en laat beter reg geskied aan die inhoud van die Skrif wat in sy geheel appellerend inwerk op die lesers. Paraklese kan eksplisiet of implisiet wees. Die twee semantiese velde wat deur die woordgroepe met dié stam gedek word, word deur Louw en Nida gegee as eerstens dit wat betrekking het op houdings en emosies, en tweedens op kommunikasie (I, 1988:xxiv).

\section{$1.2 \quad$ Metode}

Die primêre bron vir hierdie studie is die boek Romeine self in die Griekse taal. Sekonderre bronne in verskillende grade van belangrikheid is vertalings van Romeine en ook kommentare. Dit is noodsaaklik dat die primêre bron eerste en baie grondig bestudeer sal word. Dit moet liefs geskied sonder enige opskrifte en sonder hoofstuk of versindeling. Op hierdie wyse moet die makrostruktuur vasgestel word, en daarna ook die mikrostruktuur. 'n Baie konserwatiewe Bybelvertaling kan as hulpmiddel in sekere moeilike beslissings gebruik word.

Kommentare moet eers na baie worsteling met die primêre bron gebruik word. Indien dit nie gebeur nie, gly die teoloog te maklik in die groef van bepaalde verklarings in.

In elke hoofdeel wat behandel word, sal 'n poging aangewend word om die indikatief of gegewe verkondiging waarop die paraklese berus, te stel. Daarmee saam, of daarna, sal die paraklese gestel word en ook aangedui word vir wie dit bedoel is. Weens die skopus van die onderwerp en die omvang van die Romeine-brief word ondergeskikte gedagtes nie in besonderhede beredeneer nie.

\subsection{Die opset van hierdie artikel}

- Die struktuur van Romeine

- Die eerste hoofdeel:

Romeine 1:16-4:25

- Die tweede hoofdeel:

Romeine 5:1-8:39

- Die derde hoofdeel:

Romeine 9:1-11:36

- Die vierde hoofdeel:

Romeine 12:1-15:13 
Aan die einde van die artikel volg 'n bylaag waarin gedagteprikkeling vir preke uit Romeine gegee word.

\section{DIE MAKROSTRUKTUUR VAN ROMEINE}

Die Romeine-brief val uiteen in vier hoofdele met ' $n$ inleidende en afsluitende deel (Kruger, 1983:18-42):

2.1 Brief-inleiding:

Rom. 1:1-15;

2.2 Eerste hoofdeel:

Rom. 1:16 - 4:25;

2.3 Tweede hoofdeel:

2.4 Derde hoofdeel:

Rom. 5:1 - 8:39;

2.5 Vierde hoofdeel:

Rom. 9:1 - 11:36;

2.6 Briefslot:

Rom. 12:1 - 15:13;

Rom. 15:14 -16:27.

Vervolgens sal aandag gegee word aan indikatief en paraklese in die hoofdele.

\section{EERSTE HOOFDEEL: ROMEINE 1:16 - 4:25}

Hierdie deel kan beskryf word as die deel wat die belangrikste indikatief vir Romeine gee en die basis vir die res van Romeine vorm. Dit is ook die gedeelte wat die eenheid in die brief bepaal.

Watter gegewe werklikheid dui Paulus nou hier aan?

Wanneer Paulus in sy formele briefaanhef iets invoeg wat nie gewoonlik in dié formele deel voorkom nie, dui hy as 't ware prolepties aan wat nog in die brief gaan volg. In Romeine is dit van besondere belang dat ons sal opmerk wat Paulus op dié wyse insluit en wat die omvang van die ingeskuifde gedagtes is.

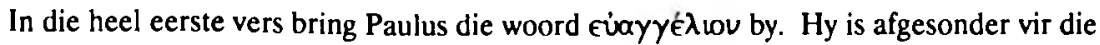
evangelie van God. "Evangelie" is bepalend vir die verdere inhoud van Romeine. Die byvoeging "van God" is belangrik. Die gedagte dat God die Vader die groot handelende is agter die gebeure wat in die evangelie verkondig word, staan sterk op die voorgrond. Volgens Romeine 1:1 was die blye boodskap van God-wat-red reeds 'n werklikheid voor die koms van Christus (vgl. Morris, 1986:25-38). 
Hierdie blye tyding is vantevore al aangekondig deur God se profete in die heilige geskrifte. Hier verwys Paulus na die Ou Testament.

Dit val op dat Paulus hierdie evangelie inhoudelik so uitvoerig beskryf - dit is 'n aanduiding van hoe belangrik dit werklik is en ook watter rol dit sal speel in die verdere dele van die brief. Die evangelie is aangaande die Seun van God. Waar nou verder meer oor die Seun van God gesê word, word dit duidelik dat Hy eintlik die inhoud van die evangelie is. Die Seun het wat die vlees betref, gekom uit die geslag van Dawid. Volgens die getuienis van die Heilige Gees is Hy sedert die opstanding aangetoon as die Seun-van-God-in-krag. Die begin van Christus se verhoging word aangedui as die begin van die tydperk waar Hy uitgewys word as die Seun-van-God-in-krag. Hier word veral na Pinkster verwys. Toe Christus aan die regterhand van God in sy heersersposisie gaan sit het, is die Heilige Gees uitgestort.

Jesus Christus is "ons" Here, die Here van Paulus en die gemeente van Rome. Van Hom het Paulus genade ontvang, en ook sy roeping tot apostel om die evangelie aan die heidene te gaan verkondig. Die werklikheid van die ontvang van genade, het vir Paulus gehoorsaamheid aan die roeping beteken. Hy het die genade nie tevergeefs

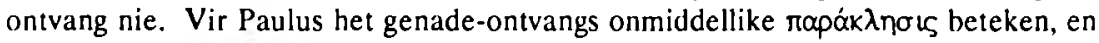

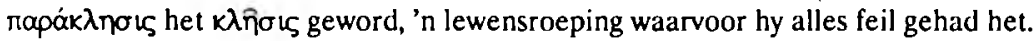

(Die uitbreiding in Romeine 1:3-4 oor Christus as inhoud van die evangelie, word algemeen aanvaar as ' $n$ vroeë belydenisformule.)

Die werkliheid van verlossing in Christus is die basis van Paulus se roeping. Daarom skryf hy ook verder van sy begeerte om die evangelie oral te verkondig en om ook na Rome te gaan. Dit is ook die rede waarom hy diegene in Spanje wil gaan evangeliseer (Rom. 1:15, vgl. 15:24), soos hy tevore die gemeente in Antiogië geëvangeliseer het, (Kruger, 1987:171).

Romeine 1:16 sluit by bogenoemde gedagte aan. Paulus skaam hom nie vir die evangelie nie, want dit is 'n krag van God tot redding vir elkeen wat glo. Die werklikheid is dat die Almagtige God aktief was in die gebeure wat deur die evangelie verkondig word. God bring so redding, owtnpia. God bewerk redding in Jesus Christus.

Die implisiete oproep, die paraklese, volg onmiddellik: glo! Wat Paulus verder sal uitwerk, stel hy nou reeds baie gedronge in Romeine 1:16-17. Daar is ' $n$ roeping om te begin glo, om die evangelie aan te neem en so Jesus Christus aan te neem. Maar daar is ook ' $n$ roeping om te volhard in die geloof. Geregtigheid word ontvang deur die 
begin-(geloof), maar dit het tot gevolg dat daar volhardende geloof sal wees. Geloof kan nie net 'n begingeloof wees nie - uit die geregtigheid kom ook 'n geloof wat volhard voort. Begingeloof en volhardingsgeloof is sowel gawe as opgawe. Dit sal Paulus later heel duidelik stel deur die waarheid van Abraham. Dit is wat Paulus

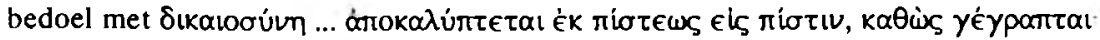

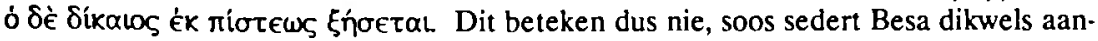
vaar is, dat die regverdige uit die geloof sal lewe nie, maar dat die regverdige (deur 'n begingeloof) sal volhard deur uit die geloof te lewe en in die dag van die finale oordeel finaal die lewe sal ontvang (Schlier, 1979:46; Kruger, 1983:91). Hierdie oproep om te begin glo, wys hoedat Paulus vir ongelowiges gepreek het. Die oproep om te volhard, geld ook vir die gemeente in Rome. Die indikatief, redding deur God en sy Seun langs die weg van geloof, en wat in die evangelie verkondig word, word nou verder deur Paulus uitgewerk in Romeine 1:18 tot 3:20.

Eerstens stel hy in Romeine 1:18-32 dat daar mense is wat die waarheid in (of: deur)

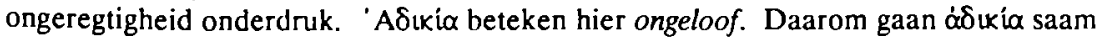
met áoé $\beta \in \iota \alpha$ in die eerste geval waar dit genoem word in Romeine 1:18 en staan dit ook in die sentrale plek as die middel waardeur die waarheid (openbaring van God) onderdruk word. Om hierdie rede staan á $\delta$ เki $\alpha$ aan die begin van die sonde-katalogus in Romeine 1:29 as die bron waaruit al die sonde voortkom en daarom moet dit ook in Romeine 2:8 weer verklaar word as ongeloof waar die inhoud van Romeine 1:18 her-

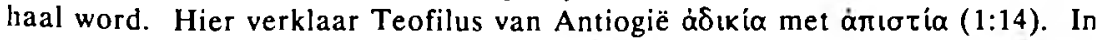

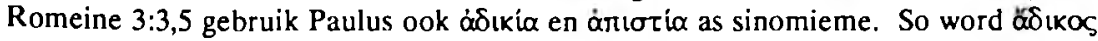
ook in 1 Korintiërs 6:9 sinoniem gebruik met ongelowige en word dit as die bron aangegee waaruit ruwe sondevolharding voortvloei. Op soortgelyke wyse gebruik Paulus ook

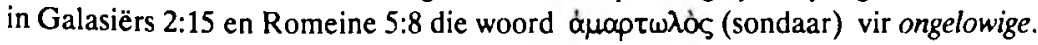

Die mense wat die waarheid in ongeregtigheid onderdruk, is nie alle mense nie. Dis duidelik uit die Grieks. By $\dot{\alpha} \nu \theta \rho \dot{\omega} \pi \omega \nu$, staan apposisioneel $\tau \hat{\omega} \nu \tau \dot{\eta} \nu \dot{\alpha} \lambda \dot{n} \theta \in \iota \alpha \nu$

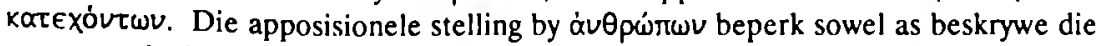
mense wat bedoel word - nie alle mense word bedoel nie, maar die onderdnukkers. Die onderdrukkers is mense wat nie positief reageer op God se openbaring nie, maar wat dit verwerp (Kruger, 1983:104-112).

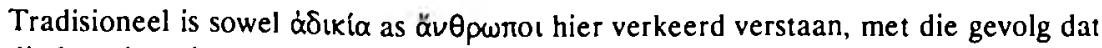
die beredenering van Paulus verder nie gevolg kan word nie. Heel onlangs nog het Sanders (1983:35) weens wanbegrip van hierdie deel beweer dat Paulus onlogies was. 
Saamgevat kan van Romeine 1:18-32 dan gestel word dat Paulus daar mense beskryf wat God se openbaring wat reeds sedert die skepping (Rom. 1:20) voortduur, onderdruk. Die veroordeling van hierdie mense is regverdig omdat, hoewel hulle God leer ken het (Rom. 1:21), hulle Hom nie verheerlik of gedank het nie, dit wil sê, Hom nie met geloof erken het nie (Rom. 1:21). ruóvt€s is 'n ingressiewe aoristos. Hierdie onderdrukkers van die waarheid is sowel mense uit die Jode as uit die nie-Jode (contra Morris, 1986:28 en Sanders, 1983:35).

Juis omdat daar by sommige Jode die opvatting bestaan het dat hulle nie gereken kan word tot die onderdrukkers van die waarheid nie, oortuig Paulus in Romeine 2:1 tot 3:8 so 'n Jood dat ook hy ingereken was in Romeine 1:18-32: dit vorm die hooflyn van hierdie hele gedeelte. Parallel hiermee wys hy egter tot beskaming van dié ongehoorsame Jood in 2:7-10, 2:14-16 en 2:26-29 dat daar wel "heidene" was wat op grond van die openbaring van die begin van die skepping af geglo het.

Dan volg Romeine 3:9-20 waar Paulus van Jode sowel as nie-Jode stel dat hulle almal skuldig is en dat niemand dus kan bekostig om die openbaring van God te verwerp nie. Dit kan alleen geskied met die sekere gevolg van veroordeling, want in die verwerping van God se openbaring word die evangelie van redding (wat altyd in God se openbaring is) verwerp, en so ook God se genade. Paulus se doel was nie om in Romeine 1:18 - 3:20 aan te toon dat alle mense sondig is nie (contra Cranfield, 1977:104; Morris, 1986:34; Sanders, 1983:35). Hy aanvaar dit eenvoudig soos Jesus as 'n feit (vgl. Ladd, 1977:55). Dit was allermins nodig om so 'n lang argument te voer om die Christene in Rome te oortuig dat alle mense sondig is. Die punt van die argument en sy betoog is dat God uit liefde kom na sondige mense, maar dat sommige van hulle dan nog sy genade verwerp in die verwerping van sy waarheid, dit is sy openbaring.

Met die wovi dè van Romeine 3:21 begin Paulus 'n stelling wat vir die lesers 'n brug slaan na die paraklese wat gegrond is op die vorige stellings van die werklikheid: God het nog sedert die skepping altyd met die bekendmaking van Homself tot alle mense gekom; sommige mense, Jode sowel as nie-Jode, het God se openbaring en so hulle redding, sy genade en Homself, verwerp; maar nou, vuvi $\delta \dot{\epsilon}$, het hierdie openbaring gekulmineer, want God het reddend in Christus gekom. God se liefde het in die geskiedenis hoër uitgereik deur nog oorvloediger te wees as in sy vorige reddende koms tot die mense. In Christus is die volle openbaring van God as God-wat-red (Rom. 3:21-26).

Die paraklese wat implisiet in die hele argument met die ongehoorsame Jood gelê het, naamlik dat God se openbaring aangeneem moet word, kom nou tot 'n hoogtepunt. 
Implisiet le in die verse wat met vuvi $\delta$ é begin, dieselfde as in Hebreërs 2:2-4: hoe sal ons ontvlug as ons só 'n heerlike openbaring (in Christus) verwerp as diegene wat veel minder ontvang het al onder die toorn was!

Romeine 3:27-31 tipeer hierdie koms en werk van Christus as alles genade en dat dit vir almal is.

Om sy hele betoog dat 'n mens God se openbaring as evangelie waardeur reddingdeur-God deur ' $n$ mens ontvang word, te verduidelik, gee Paulus dan in Romeine 4 die voorbeeld van Abraham. Abraham het toe hy nog in die heidendom was, geglo dat God vir die goddelose ( $\alpha \sigma \epsilon \beta \hat{n}$ - Rom. 4:5) geregtigheid toereken as hy glo. So het hy

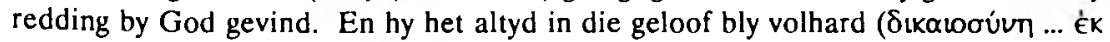

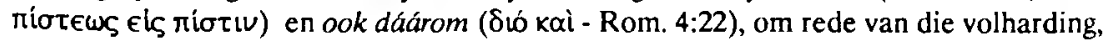
is sy geloof tot geregtigheid gereken. Abraham het al geglo dat God uit die dood kan opwek (Rom. 4:17). Vir Paulus en sy medegelowiges het God in Christus gewys dat Hy uit die dood lewend mak.

Implisiet is die paraklese duidelik: kyk na wat God in Christus gedoen het en maak soos Abraham! Neem Christus as Redder aan in die geloof en volhard daarin soos Abraham! So sal julle ook soos Abraham wees wat weet dat God die goddelose mense regverdig (Rom. 4:5) en dat redding alleen uit genade is (Rom. 4:16).

Die oproep dat die mense in Rome en die mense wat die openbaring, die evangelie van Jesus Christus hoor, dit met geloof moet aanneem en daarin moet volhard, word eksplisiet gestel as Paulus vervolgens in Romeine 4:23-25 stel dat wat hy vertel het van Abraham, en dus in die hele voorafgaande deel, nie alleen maar geskryf is ter wille van kennis oor Abraham nie, maar ter wille van "ons", Paulus, Romeine en almal wat met die evangelie in aanraking kom. Hulle moet glo en volhard in die geloof.

\section{TWEEDE HOOFDEEL: ROMEINE 5:1 - 8:39}

Die strukturele teenhanger van Romeine 5:1-11 is Romeine 8:31-39. Dieselfde elemente kom voor in albei gedeeltes. Alles kan saamgevat word in die woorde $\dot{\epsilon} k$

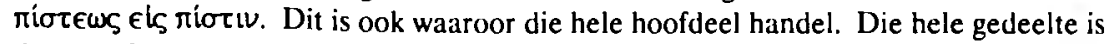
daarop afgestem om bemoediging te wees. Paulus het hier diegene wat reeds in Christus glo in gedagte. So sluit dit aan by die einde van die vorige hoofdeel wat gestel het dat die indikatief van Abraham se vertroue in God nie ter wille van hom alleen daar gestel is nie, maar ter wille van "ons". 


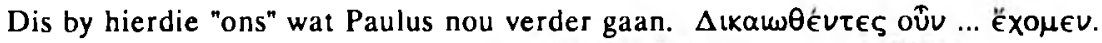

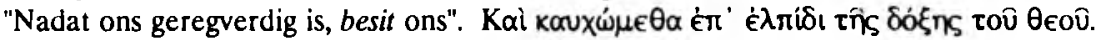

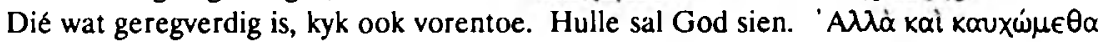

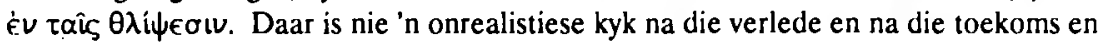
ook die hede nie. Nee, die verdrukkinge word ook raakgesien en positief beoordeel. Die verdrukkinge beteken wel lyde, maar lyde wat dien tot geloofsvolharding. Paulus redeneer hier van minder na meer. Toe ons nog ongelowig was ( $\dot{\alpha} \mu \alpha p \tau \omega \lambda \omega \omega)$ (Rom. 5:8), goddeloos ( $\dot{\alpha} \sigma \in \beta \bar{\omega} v$ - Rom 5:6), het God se Seun vir ons gesterf. Toe ons nog vyande was (éx日poi - Rom. 5:10), is ons versoen met God. Hoeveel te meer kan ons dan seker wees van sy liefde noudat ons versoen is! In die oordeel sal ons sekerlik gered word. Op grond hiervan dan die paraklese: laat ons seker wees daarvan en bly volhard en glo dat ons in die oordeel vrygespreek sal word.

Reeds in hierdie gedeelte troos Paulus die gelowiges met die herinnering van die Gees wat in ons harte is, die eersteling van die volle som.

In Romeine 5:12-21 word die hoofgedagte van insluiting in Christus behandel en word die parallel tussen Adam en Christus hier gestel. Voor die koms van die wet al het die dood geheers weens die insluiting in Adam. Dit is dus nie eers deur die oortreding van die wet wat later gekom het, dat die dood ingetree het nie. Die wet het egter die betekenis gehad dat die oortreding meer geword het. Die wet is ook vir hierdie doel

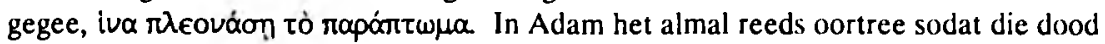
oor hulle geheers het. As die wet nou bykom sodat die oortreding daardeur duideliker en moedswilliger is, word die sonde meer wanneer iemand nogtans, nieteenstaande die duidelike wet, steeds sondig. Maar as Christus nou mense in Hom insluit wanneer hulle weliswaar nie net in Adam gesondig het nie, maar ook die wet wat later gekom het oortree het, dan is die genade wat in Christus deur die geloof ons deel word, nog

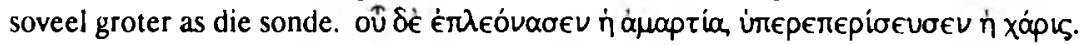

In bostaande gedeelte is dit duidelik hoe onuitspreeklik groot die waarde van die insluiting in Christus deur die geloof is: dit is sodanig dat selfs al het 'n Jood die wet oortree, maar hy nou tot geloof in Christus kom, die geregtigheid hom volkome toegereken word en dat die genade al sy skuld uitwis. Die ryk troos om in Christus te wees, word so beklemtoon veral vir die Jode.

Dit is teen hierdie agtergrond dat Romeine 6 nou gesien moet word. As ons dan sonder wetsonderhouding, ja selfs met wetsoortreding, wetende wat die wet eis, nogtans gered word en die genade dan soveel groter is teen die agtergrond van die vergrote oortreding, moet ons dan nie dieselfde resep volg om nóg meer genade te 
Page not available 
Page not available 
Die hart van die vertroosting lê in die aanwesigheid en werk en hulp van die Heilige Gees. In 8:1-17 staan hierdie gedagte sentraal. Die wet, dat die Gees in ons is, die werklikheid van die Gees wat lewe gee deur Christus, het ons bevry van die sonde-endood werklikheid. God verlos deur Christus en gee ons die Gees. Ons is dus nie meer in die vlees nie, maar die Gees is in ons. God sal ons lewend maak deur die Gees. Ons moet deel hê aan die werk van lewendmaking deur die sonde dood te maak. Ons weet tog die Gees is in ons. Hy laat ons dan God Abba noem. Dit is 'n kind wat $A b b a$ sê, en 'n kind sal volle erfgenaam wees. Heerlike troos!

In 8:18-30 word die twee werklikhede, naamlik die besit van die Gees as eersteling en die lyde wat daar nog vir kerk en skepping is, gestel. Die besit van die Gees is die waarborg van uiteindelike volle oorwinning. Die aanwesigheid en hulp van die Gees lê die hele ketting van God se reddingshandeling bloot (Rom. 8:29-30).

In Romeine 8:1-30 word die gelowiges opgeskerp om die Heilige Gees in hulle op te merk. Wie dan weet dat die Gees in hom is, werk en leef te midde van beproewing, getroos en met verwagting van die volheid.

Om hierdie rede sluit Paulus af met 'n oorwinningslied (Rom. 8:31-39).

\section{DERDE HOOFDEEL: ROMEINE 9-11}

Hierdie hoofdeel val uiteen in drie dele, naamlik Romeine 9:1-29, 9:30-10:21 en 11:132.

In die eerste onderdeel, Romeine 9:1-29 spreek Paulus sy droefheid uit oor dié deel van Israel wat ongelowig is. God het egter nie sy verbond verbreek nie, maar sy

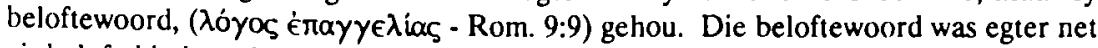
vir beloftekinders. Dit geld vir dié wat geroep en verkies is. Volgens sondige menslike oordeel lyk die handeling van God arbitrêr. Paulus stel dit egter dat God soewerein is en dat redding afhang van sy barmhartigheid. Diegene wat verhard is, het hulleself verhard teen God se openbaring. Daarenteen het God dié wat gered word, voorberei vir

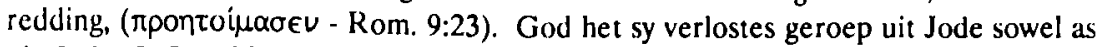
nie-Jode. In Israel is slegs die saad (geloofskinders) van Abraham as oorblyfsel gered.

In die tweede onderdeel van Romeine 9-11, naamlik Romeine 9:30 - 10:21 kom daar ' $n$ sterk klem op geregtigheid en geloof. Dit sluit onmiddellik weer aan by Romeine 1:17. 
Daar is die nouste verband tussen die geregtigheid en geloof en God se kommunikasie, sy Woord wat naby is. In die tyd waarin Paulus skryf, staan hy voor die werklikheid dat sommige nie-Jode die evangelie aangeneem het, terwyl soveel Jode dit nie gedoen het nie. En dit gebeur ondanks die ywer wat baie Jode gehad het vir God. Dit is dus eie geregtigheid in plaas van om geregtigheid as 'n genadegawe van God te ontvang. Hulle moes met geloof deurgedring het tot by God en met die God van die wet in 'n liefdes-en vertrouensverhouding te staan gekom het, maar het nie verder as die uiterlike van die wet gekom nie. Hulle het nie tot by die hoeksteen wat God in Sion gelê het, gekom nie. In Deuteronomium, waarna Paulus verwys in hierdie deel, word herhaaldelik gewys op God se liefde. Hy is die Here wat na hulle toe gekom en hulle verlos het. In dié gedeelte wys Paulus dat Christus die werklike hart van die wet was, die

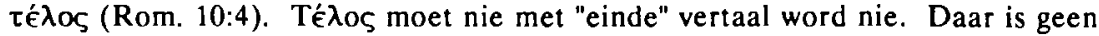
teenstelling tussen wet en evangelie, of Christus en Moses nie (Kruger, 1988:84). Om die wet te doen sodat jy kan lewe soos Moses gesê het, beteken om by hierdie hart van die wet te kom. Totnoas, (Rom. 10:5), lê geheel en al op die vlak van wat Jesus volgens Johannes 6:28-29 gesê het. "Die werk van God" is om te glo in Hom wat die Vader gestuur het. Paulus wys dat God met sy reddende kommunikasie altyd naby is. Al sy kom-tot-mense is voldoende om hulle te red. Wanneer God tot mense kom, vra Hy geloof, vertroue en dit is wat Paulus nog steeds verkondig: almal moet glo. Vir Israel was die Woord ook altyd naby. Alreeds die openbaring wat sedert die skepping in die natuur, geskiedenis en gewete voortgeduur het, was voldoende om hulle te bring by God-wat-red. Hoeveel te meer moes hulle met geloofsvertroue by Hom gekom het nadat hulle 'n soveel helderder openbaring van God ontvang het! God het egter tevergeefs gepleit by baie Jode. Hulle het Hom afgewys. Aan die ander kant het juis nieJode gehoorsaam die verkondiging aangeneem.

Die derde onderdeel wys dat God nie sy ou verbondsvolk verstoot het nie. Daar is ook 'n "ekonomie" in die gebeure. Juis die feit dat baie Jode die evangelie nie wou aanneem nie, het veroorsaak dat die evangelie deurgestuur is na nie-Jode. Miskien sal die Jode deur jaloersheid tot God kom. Romeine 11 bevat ook 'n ernstige waarskuwing teen wat genoem kan word verbonds-outomatisme by die nuwe Israel. Indien daar nie die ware geloof is by hulle nie, kan ook hulle soos droë takke afgekap word.

Implisiet in hierdie hoofdeel, Romeine 9-11 lê die appèl op ongelowige Jode om Christus en so geregtigheid en genade aan te neem deur nie God se evangelie af te wys nie. Dit is deur die kommunikasie van God aan te neem, en veral noudat Christus gekom het as dié kommunikasie, dat hulle gered kan word. Paulus is dus ook in hierdie deel nog by wat reeds in Romeine 1:1-4 aangevoer is. Hy is ook nog steeds by die 
implisiete pleidooi van Romeine 1:18 dat hulle nie onderdrukkers van die waarheid moet wees nie. Verder lê Paulus ook die voorbeeld van die ongehoorsame Israel voor die nuwe Israel met die ernstige vermaning dat hulle moet waak daarteen dat dieselfde gebeur. Uiterlike toebehoort tot die verbond en vertroue wat nie op God gerig is nie en op eie kragte oorgaan, sal dieselfde tot gevolg he as by die ongelowige deel van Israel.

\section{DIE VIERDE HOOFDEEL: ROMEINE 12:1 - 15:13}

Onmiddellik wanneer Paulus hier kom by 'n parakletiese gedeelte wat eerstens direk tot die gemeente in Rome gerig is, kom hy weer terug op wat tevore reeds in die brief gestel is. As hy sê dat die gemeente in Rome hulle liggame moet stel as lewende en dankbare offers, dan staan dit teenoor die onderdrukkers van die waarheid wat hulle liggame aan die sonde gegee het (Rom. 1:26-27). In Romeine 6:12-14 het hy ook die eis gestel dat liggaam en gees vir die Here moet wees. Die gelowige moet 'n nuwe mens wees. Daarom handel Paulus hier ook oor die denke wat vernuwe moet word.

In hierdie hele hoofdeel kan ons die paraklese indeel onder drie hoofde sover dit menslike verhoudinge betref. Die gelowiges is in Christus en daarom moet hulle in die eerste plek self steeds meer die beeld van Christus vertoon; tweedens moet hulle as gelowiges optree teenoor die owerhede en almal buite; derdens - 'n baie belangrike deel - moet hulle teenoor mekaar optree soos Christus teenoor hulle. Hulle moet mekaar aanvaar.

Venter (1985:193-198) kom in sy proefskrif Die Pauliniese paranese in Romeine 12:1 15:13 tot die gevolgtrekking dat daar in hierdie hele gedeelte drie temas is wat die paranese beheers, naamlik 'n eskatologiese, 'n liefdes- en 'n ekklesiologiese tema. Daarby stel hy ook dat die paranese 'n trinitariese karakter het (1985:196). Die menslike verhoudinge en die paraklese ten opsigte van die drie groepe moet in die nouste verband met hierdie aspekte gesien word.

Romeine 12:1-2 eis dan liggaam en gees op vir die Here. Dit is 'n dankoffer omdat God hulle uit vrye genade in Christus aangeneem het.

Onderlinge aanvaarding, liefde en diens vir mekaar is die temas van Romeine 12:3-16.

Met verse 17-21 kom 'n oorgang wat oproep tot die regte verhouding ook met ongelowiges, dié wat buite is. Selfs teenoor die vervolgers moet opgetree word met liefde. 
Hierby aansluitend is die oproep tot gehoorsaamheid aan die owerheid wat 'n dienskneg van God is (Rom 13:1-7).

Die gedeelte Romeine 13:8 tot 15:7 kulmineer in die oproep van Romeine 15:7: die mense in Rome moet mekaar aanvaar soos Christus hulle ook aanvaar het tot heerlikheid van God. In die gemeente van Rome was daar sterkes en swakkes, mense wat nie almal eenders gedink het oor feesdae en voedsel nie. Hulle moet vir mekaar ruimte maak. Daar was Joodse Christene en heiden-Christene, daar was here en slawe. As kosmopolitiese stad sou daar waarskynlik 'n groot verskeidenheid mense in dieselfde gemeente wees wat etnisiteit en kulturele ontwikkeling betref. Paulus sê dat dit erediens is as hulle mekaar aanvaar. Juis daaruit blyk hoe hulle werklik verstaan wat dit beteken het dat die Heilige God hulle in Christus aangeneem het.

In Romeine 15:8-13 kom Paulus in aansluiting by die vorige deel weer terug op die indikatief van die werk van Christus en bring hy lof toe aan God.

\section{SAMEVATTING}

Om oor indikatief en paraklese in Romeine te skryf, is 'n omvangryke taak - daarom is slegs hooflyne getrek. Dit het egter die voordeel dat 'n oorsig oor die hele boek en insig in sy struktuur duideliker kan wees. Die paraklese is algemeen in sover dit gerig is op alle mense en alle Christene; dit is besonder in sover dit gerig is op onbekeerde Jode en ook spesifiek tot die gemeente in Rome. Die geheel van die paraklese rus op die indikatief van Romeine 1-4 wat God se openbaring tot redding verkondig.

\section{BYLAAG: GEDAGTEPRIKKEIING VIR PREKE UIT ROMEINE}

\section{OM TE LEEF UIT GENADE}

1. Romeine 1:1-4 en 1:14-17 (Kernvers 1:1)

Redding deur die evangelie

1.1 Al die openbaring van God aan die mense is evangelie, blye boodskap, omdat God Self daarin kom tot sondige mense sodat hulle Hom kan ken as Redder. 
1.2 Reeds in die ou bedeling het God Homself reddend geopenbaar (1:2, 3:2). Ook sedert die skepping (1:19-20). Vergelyk byvoorbeeld Hosea 13:4 en 14 en daarna 12:7.

1.3 In Christus kom God Self tot die mense in die hoogste openbaring. Dit dring Paulus. (vgl. Hebreërs 1:11).

2. Romeine 1:18-32 (Kernvers 1:18)

Moenie die waarheid van God onderdruk nie

2.1 God se waarheid is sy Self-openbaring - dit is evangelie, want wie gehoorsaam reageer op hierdie openbaring, dit aanneem, word gered van God se toorn.

2.2 Daar was egter altyd mense wat hierdie openbaring deur ongeloof (ongeregtigheid) onderdruk (1:18). Nie alle mense word hier bedoel nie. Alle mense is sondaars, maar almal is nie onderdrukkers van God se waarheid en verwerpers van sy openbaring nie.

2.3 Onderdrukkers van God se waarheid leer Hom genoegsaam ken (1:21) sodat hulle Hom sal kan verheerlik en dank (1:21).

2.4 Juis omdat sodanige mense dan die openbaring onderdruk en progressief dieper in afgodediens en sonde gelei word deur die boosheid in hulle harte, gee God hulle oor aan wat hulle begeer $(1: 24,26,28)$. So begin sy toorn reeds in hierdie lewe al oor hulle kom.

(Vergelyk by hierdie preek artikel 2 (Nederlandse Geloofsbelydenis) wat stel dat die skepping, onderhouding en regering van die hele wareld reeds genoegsaam is om die mense te oortuig en hulle alle verontskuldiging te ontneem.)

Dit is belangrik om God se voortgaande persoonlike bemoeienis met alle mense op te merk. Hier is nie maar sprake van 'n "algemene openbaring" waaruit ons afleidings moet maak nie. Nee, God Self spreek tot ons in die skepping, geskiedenis en gewete. Romeine 1:19 sê: God het dit aan (beter: vir) hulle geopenbaar. Dit is 'n persoonlike koms van die heilige God na mense wat hulle rug op Hom gekeet het. Onderdrukkers van die waarheid is dus verwerpers van God se genade en liefde. 


\section{Romeine 2:1 - 3:8 (Kernvers 2:1)}

\section{Selfbedrog oor jou staat voor God}

Hierdie deel is 'n diatribe-argument van Paulus met 'n fiktiewe ongehoorsame Joodse gespreksgenoot - dit vorm die hooflyn van die betoog. (Daar is 'n sub-lyn wat in die volgende preek aan die orde kom.)

Hierdie Jood is ook 'n onderdrukker van die waarheid. Hy het die wet gehad en is besny. Hy het egter nooit by die hart van die wet uitgekom nie, naamlik dat God reddend kom in al sy openbaring en dat'n mens jou redding deur geloof en vertroue van God alleen moet verwag nie. Hierdie hart of wese van die wet word in 2:7 épyou $\dot{\alpha} y \alpha \theta$ ou (L.W. nie van goeie werke nie, maar van 'n goeie werk) genoem, in 2:15 tò Ěp you toû vópoû (vgl. Joh 6:28,29). In Romeine 10:4 word hierdie hart van die wet

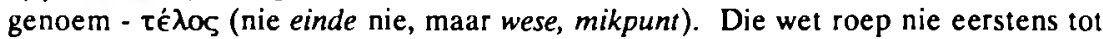
werke nie, maar tot vertroue op God wat red.

Met die Bybel in die hand, terwyl iemand gedoop is, kan hy nog op pad wees na God se ewige veroordeling.

\section{Romeine 2:7-10, 2:14-16, 2:26-29 (Miskien as teksverse 2:26-29)}

Hoe groot is God se genade!

Ingevleg in die hooflyn van Romeine 2:1 - 3:8 is die sub-lyn van "heidene" wat gered is, sonder dat hulle die openbaring wat aan die Jode gegee is of die openbaring in Christus ontvang het.

Nader omlyn: 2:7-10 is 'n chiasme waar in vers 7 en 10 gesê word dat elkeen (6) gered sal word in die eindoordeel. In 2:14-16 word van "heidene" gepraat wat gered word, in 2:26-29 van onbesnedenes wat die wet volbring en wie se harte besny is. Hulle is dus eintlik "Jode" - mense wat God loof.

Hierdie "heidene" is nie heiden-Christene nie. Paulus handel hier oor mense wat nie van die openbaring van die Jode of die openbaring in die koms van Christus kennis gehad het nie. Dit is mense wat die eerste deel van die openbaring wat in artikel 2 (Nederlandse Geloofsbelydenis) genoem is, alleen ontvang het en nie onderdruk het nie. 
Die twee foute wat gemaak word in die verklaring van Romeine 1:18-21, is ten eerste dat mense in 1:18 opgeneem word as alle mense, terwyl dit net gaan oor onderdrukkers van die waarheid. (Mense soos Melgisedek is hier in 1:18 ter sprake.) Ten tweede word nie opgemerk dat Paulus in Romeine 1:18 - 3:2 slegs handel oor die tydperk of bedeling waar alleen die openbaring volgens 1:20 ter sprake is nie, dit wat sedert die skepping voortduur.

Paulus takel dus volgens die vorige preek en hierdie een die hoogmoed van 'n ongelowige Jood af.

Ten slotte: ook Calvyn verwys meer as een keer na bekeringswerk van die Heilige Gees sonder die openbaring van die Ou en Nuwe Testament.

\section{Romeine 3:9-20 (Kernvers 3:10)}

Alle mense is die dood skuldig

Hoe kan iemand dit waag om God se koms in genade en liefde af te wys en op jouself te vertrou! Ons is tog almal, elke mens, sondig en behoort veroordeel te word. Ons word veroordeel as ons nie in Christus ingesluit is nie. Om in Christus ingesluit te wees, beteken dat ons God se openbaring aanneem.

\section{Romeine 3:21-26 (Kernverse 3:21-22)}

God se heerlike koms in Christus

Met vuul $\delta$ è van Romeine 3:21 kom 'n groter keerpunt. Paulus het reeds gewys op God se koms na die sondige mense in die openbaring sedert die skepping (1:20) en in die woorde aan die Jode (3:2). Nou het God Self egter in Christus gekom.

Daar kan vanuit 'n bepaalde hoek gesề word dat God eintlik met die groter verwording in die wêreld altyd sterker tot die wêreld gekom het.

As reeds by die vorige openbaring mense onder die toorn gekom het omdat hulle dit onderdruk het, hoe sal ons dan ontkom as ons die apostoliese woord oor God wat in Christus self gekom het, verwerp. (vgl. Hebreërs 2:3). 
7. Romeine 4:21-25 (Kernverse 4:3b en 22-25)

Glo (vertrou) soos Abraham

Abraham is as goddelose geroep (Josua 24:2 en Rom. 4:5). Hy het 'n begingeloof gehad maar ook 'n volhardingsgeloof ( $\delta$ io $\mathrm{kal}-4: 22)$. Geloof is net ' $\mathrm{n}$ ware geloof as dit volhardend vertrou. In Romeine 4 kan glo telkens vervang word met vertrou. Geloof is kennis en vertroue. Lê ons genoeg klem op vertroue?

Paulus het in sy sendingwerk ervaar dat die volgende voorkom:

- Geen begingeloof - die evangelie word verwerp.

- Geen volhardingsgeloof (vgl. 1 Joh. 2:19).

Die oproep in 4:23-25 is dat al die Nuwe-Testamentiese gelowiges moet volhard soos Abraham. Romeine 5-8 gaan juis hieroor.

8. Romeine 5-6 (Kernverse van hooflyn 6:12-14)

Weer eens: Hoe groot is God se genade

8.1 Reeds voor die koms van die wet is mense die dood skuldig weens insluiting in Adam.

8.2 Wie die wet oortree na die ontvangs daarvan, se skuld word vergroot.

8.3 Maar al is ons ingesluit in Adam, al het ons nog die eksplisiet gegewe wet oortree, as ons deur die geloof in Christus is, is sy genade só groot dat al ons skuld uitgewis word. (Ook besonderlik tot 'n Jood gerig.)

8.4 Sal ons dan nog sondig?

8.5 As ons glo, is ons in Christus ingesluit. As ons in Hom ingesluit is, het ons saam met Hom deur sy dood betaal vir ons sonde. As ek dan saam gesterf het om te betaal om vry te wees van my sonde, hoe kan ek weer wil sondig? 
9. Romeine 7:7 - 8:39 (Baie preke moontlik. Hou net die booflyn in gedagte.)

Christene: strydende oorwinnaars

9.1 Daar is nog stryd vir 'n gelowige: stryd geleè in getuie-wees - maar nie die minste nie - stryd in die eie gemoed.

9.2 Daar is twee "wette" in ons. Die eerste: die gees het my wil verander sodat ek nie meer wil sondig nie. Die tweede: die bose neiging kom nog altyd op en word ook dade.

9.3 Dank God dat langs die weg van Christus ( $\delta \dot{a})$ die oorwinning reeds verseker is.

9.4 Die Gees wat in my is en my laat bid $A b b a, V a d e r$, is die pand van die volle erfenis.

9.5 Daarom is ek oorwinnaar in al hierdie dinge (8:37).

10. Romeine 9:1-29 (Kernverse 9:6 en 9:16)

Die soewereine God het nie almal in ou Israel uitverkies nie

10.1 God het slegs sy belofte aan die uitverkorenes in Israel toegesê

10.2 Diê wat nie belofte-kinders is nie, is self verantwoordelik vir hulle verharding. "... voorberei vir die verderf ..." is nie 'n passivum divinum nie. Hulle het hulleself daarvoor voorberei, maar in sy lankmoedigheid het God hulle verdra.

10.3 Paulus handhaaf die volgende openbaring sonder rasionele uitrekening:

Redding: genade van God

Verderf: eie verantwoordelikheid. 
11 Romeine 9:30 - 10:28 (Kernvers 10:8)

Naby jou is die woord!

God kommunikeer altyd met alle mense sodat hulle gered kan word. Die woord het in verskillende gestaltes gekom:

- In die gestalte van die skepping (Ps. 19, Rom. 10:18). As 'n Jood sou wou sê dat hy miskien nie gehoor het nie (10:18) dan kom die antwoord: Onmoontlik! Paulus haal aan uit Psalm 19:4.

- In die gestalte van woorde aan die Jode (3:2).

- In die gestalte van Christus (3:21).

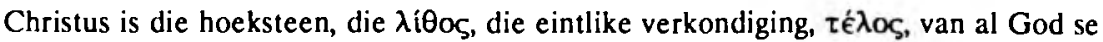
kommunikasie. Wie met geloofsvertroue antwoord op God se openbaring, in watter bedeling ook al, is in Christus - ook al het hulle nooit van Jesus gehoor nie.

Hoeveel meer moet ons nie glo nie - ons wat die Skrif het!

12. Romeine 11 (Kernvers 11:20)

"Die tempel van die Here, die tempel van die Here" (Formalistiese godsdiens)

Nie almal is Israel wat Israel genoem is nie - alleenlik die ware gelowiges wat op God se openbaring met vertroue op Hom geantwoord het.

So kan ook in die kerk diegene aanwesig wees wat gedoop is, 'n Bybel het, kerk toe kom, rondom die dinge van die "kultus" formeel getrou is, maar tog nie waarlik in diepe afhanklikheid hulle redding van die Here verwag nie. (vgl. 3 oor Rom. 2:1-3:8.) Ook hulle sal soos droë takke afgekap word.

13. Romeine 12:1 - 15:13 (Uitgesluit 12:17 - 13:7)

Aanvaar mekaar! (15:7)

13.1 Romeine 15:7 is 'n samevatting van 12:3 - 15:13. 
13.2 Hierdie samevatting bestaan uit drie dele:
a. Aanvaar mekaar,
b. soos Christus julle aanvaar het
c. tot heerlikheid van God.

13.3 "mekaar" is sterkes en swakkes (vgl. 14:1-12), here en slawe, gelowiges uit die heidene en gelowiges uit die Jode, mense met kulturele en etniese verskille.

13.4 Kan iemand weet hoe groot die genade is dat Christus hom aanvaar het (vgl. Fil. 2:5-8), as hy nie sy medegelowige wil aanvaar nie?

13.5 Om mekaar te aanvaar, is erediens aan God. Erediens is nie net wat ons gewoonlik dink nie.

13.6 Wat 'n belangrike boodskap vir die gelowiges in Suid-Afrika!

14. Romeine $12: 17-21$

Christene se gedrag teenoor buitestaanders

15. Romeine 13:1-7

Christene en die owerhede

God werk ook deur heidense owerhede. Ons moet ons onderwerp aan alle owerhede, behalwe waar hulle tussen ons en ons diens aan God kom.

\section{BIBI IOGRAFIE}

CRANFIELD, C.E.B. 1977. A critical and exegetical commentary on the epistle to the Romans. Vol 1. Edinburgh : Clark.

KRUGER, M.A. 1983. Openbaring, geloof en geregtigheid. Pretoria (Ongepubliseerde proefskrif, Universitcit van Pretoria.)

KRUGER, MA. 1987. Tina Karpon, "Some fruit" in Romans 1:13. WTJ, 49: 167-173.

KRUGER, M.A. 1988. Naby jou is die Woord! Romeine 10:8. (In Coetzee, J.C. red. Koninkryk, Gees en Woord). Pretoria : NG Kerkboekhandel. 
LADD, G.E. 1979. A theology of the New Testament. Grand Rapids : Eerdmans.

LEKKERKERKER, A.F.N. 1962. De brief van Paulus aan de Romeinen. Vol I en II. Nijkerk: Callenbach.

LOUW, J.P. \& NIDA, E.A. 1988. Greek-English lexicon of the New Testament based on semantic domains, 2 vols. New York : United Bible Societies.

MORRIS, L. 1986. New Testament Theology. Grand Rapids : Zondervan.

SANDERS, E.P. 1983. Paul, the law, and the Jewish people. Philadelphia : Fortress Press.

SCHLIER, H. 1979. Der Römerbrief. Freiburg : Herder.

VENTER, CJ.H. 1985. Die Pauliniese paranese in Romeine 12:1 - 15:13. 'n Eksegetiese studie. Potchefstroom (Ongepubliseerde proefskrif, (Th.D) - PU vir CHO.) 